Article

\title{
The Evaluation of Universities' Third Mission and Intellectual Capital: Theoretical Analysis and Application to Italy
}

\author{
Rocco Frondizi, Chiara Fantauzzi *, Nathalie Colasanti and Gloria Fiorani \\ Department of Management and Law, University of Rome “Tor Vergata”, 00133 Roma, Italy; \\ rocco.frondizi@uniroma2.it (R.F.); nathalie.colasanti@uniroma2.it (N.C.); gloria.fiorani@uniroma2.it (G.F.) \\ * Correspondence: chiara.fantauzzi@uniroma2.it; Tel.: +39-06-7259-5900
}

Received: 29 April 2019; Accepted: 17 June 2019; Published: 24 June 2019

\begin{abstract}
From being entities for knowledge creation and dissemination, universities are now asked to play an increasingly entrepreneurial role, involving networking and collaboration, as well as sustainability and social engagement. This consideration is in line with the fourth-stage intellectual capital perspective, which focuses on knowledge creation with an ecosystem focus. But which are the main approaches to manage and evaluate this new role? Can intellectual capital contribute to this evaluation process? The paper aims to answer these research questions by systematizing the theoretical contributions on this topic; it is based on the following steps: First, a brief historical overview of the evolution of the role of universities; secondly, a literature review on university's third mission and its relationship with intellectual capital; finally, an analysis of the different approaches for evaluating this mission. Despite the academic and institutional efforts, there is little agreement on a set of indicators to evaluate quality in university's third mission activities. In Italy, an "intellectual capital maturity model" (ICMM) has been built, but it needs further applications and evaluations.
\end{abstract}

Keywords: evaluation; intellectual capital; third mission; university-business-government relations; Italy

\section{Introduction}

In 2012, European Commission and OECD [1] stated that "higher education is facing unprecedented challenges in the definition of its purpose, role, organization, and scope in society and the economy". In particular, universities and other research institutions are becoming progressively aware of their crucial role for the economic and social development, since it is increasingly acknowledged that the scientific and technological knowledge that they produce can be useful to business. Their economic and social role influences the way they define and measure their intellectual capital, which can be used as an assessment instrument for evaluating the performance of universities in the field of "third mission" [2].

The knowledge economy is recognized as the reference model for most production processes in many economic sectors. Powell and Snellman [3] define the knowledge economy as "production and services based on knowledge-intensive activities that contribute to an accelerated pace of technical and scientific advance, as well as rapid obsolescence". Indeed, public research institutions not only generate and disseminate knowledge, but are also called to transfer their findings, in various ways, to science-related communities, such as industries and commerce. Indeed, universities are fundamental actors in the knowledge-based society.

What is stated above is also present in the open innovation model [4], in which knowledge resources coming from outside the firm, including universities, play a key role in the development of 
business innovation processes. This has modified the traditional business-university relationships, thus, especially resulting in an evolution of the role of the latter. This evolutionary process, resulting in the third mission theory, is consistent with the transition from the second to the fourth stage perspective in intellectual capital (IC) theory. At the beginning of IC studies, universities were considered the subject of research and, according to the second-stage IC perspective [5], investigations were mainly on intellectual property, management, research and development, and reporting. Then, in a third-stage perspective [6], attention translated to IC practice inside universities [7-9], and, finally, the fourth-stage IC perspective advocates for knowledge creation with an ecosystem focus [10]. In fact, the creation of knowledge by ecosystems (be they national or local ones), and not by individual organizations, is aligned with the third mission approach, where universities build ties and relationships with their local communities to enhance their development and create shared knowledge. Thus, it is clear that the adoption of an IC perspective (measurement models and management approach) aims to improve the internal management, create new teaching and research strategies [8], allocate public resources, and interact with different stakeholders correctly [11], by promoting the development of the third mission within the university.

The triple helix model [12,13] analyzes university-business-government relationships. It argues that, in a knowledge-based society, universities can foster innovation and economic development; it also states that a hybridization of elements from universities, industries, and governments is needed to generate new institutional and social arrangements for the production, transfer, and application of knowledge. This vision encompasses not only the process of creative destruction [14], but also the creative renewal emerging within and between the three institutional spheres. The triple helix model has recently evolved to include a fourth helix, represented by the "media-based and culture-based public" and the "civil society" [15], and a fifth helix, represented by the "natural environments of society" [16].

The triple, quadruple, and quintuple helix models are strictly entwined and interdependent with the third mission policy approach. These concepts define the role universities are expected to play in the process of innovation and sustainable development in contemporary times. Governments would, as a matter of policy, like to ensure by means of funding mechanisms that universities are positively engaged in regional and national development through the pursuit of research and development, leading to innovation, knowledge exchange, and technology transfer, also favoring sustainability. The triple helix is a response to policy concerns, also representing an attempt to engage in a much wider discussion about the national innovation system (NIS) concept initiated by Freeman [17] and Lundvall [18]. Whereas the NIS would seek to retain the benefits of globalizing knowledge within specified geographical boundaries, the helices underpin the study of innovation systems at various levels of institutional and functional categories, thus, enriching the conceptual and empirical dimensions of innovation as a systemic phenomenon, improving the effectiveness of innovation policies at regional and national levels, and ultimately operationalizing the third mission approach [19].

As a policy imperative since the emergence of research and development practices in the post-second world war period, third mission models state that, besides teaching and research, universities should contribute to the local socio-economic development, in the growing conviction that scientific research results and educational skills are crucial for the economic growth of nations. All third mission actions are carried out in the belief that the prerequisite for the socio-economic development and growth of a region is the ability to trigger "virtuous co-evolutionary circles" [20-22] between research, education, technology, business, and services, thus, fostering the enhancement of the intangibles represented by the social capital of a region (e.g., culture, traditions, environment, lifestyle, social inclusion, and cohesion). Third mission activities facilitate the shift towards an "entrepreneurial university" [23].

In order to meet the third mission challenges and, therefore, to push the frontiers of knowledge and to let universities become a powerful engine for innovation and economic growth, in recent times, specific operative infrastructures have been founded or reoriented in universities all around 
the world. Furthermore, several attempts have been made to find commonly agreed indicators and methodologies to evaluate and compare the extent to which third mission activities are carried out in different institutions and countries. The fourth-stage IC perspective presents itself as a useful framework for tackling these issues, given its correspondence with the third mission theory and with the necessity to face the challenges that emerge for traditional universities.

The objective of the paper is to shed light on the new role of universities in the current social and economic environment, by answering the following research questions: Which are the main approaches to manage and evaluate this new role? Can intellectual capital contribute to this evaluation process? By adopting the fourth-stage IC perspective, the paper will assess whether IC is useful for managing third mission variables and activities. Moreover, the application of an IC approach to research on universities is consistent with their activity of knowledge production and transfer, and this has been acknowledged in recent years [24]. For the purposes of this paper, the definition of IC to be employed is the one by Stewart [25], adapted by Secundo et al. [24], and based on considerations regarding the specific nature of universities and their activities.

The paper is organized as follows. Section 2 provides the theoretical framework of the paper, which is organized in three parts: First, we review the role of universities from their origins up to today; secondly, we present an overview of the literature on the new role of universities and on third mission, and finally, we analyze the relationship between third mission and intellectual capital. Section 3 describes the methodology adopted to analyze findings, presented in Section 4. Finally, Section 5 will be dedicated to discussion and conclusions.

\section{Theoretical Framework}

This section builds the theoretical framework of the paper on two pillars. First, we analyze the evolution of the role of universities from their origins up to the present day, and then we provide an overview of the literature on the specific issue of the new role of universities, which in turn calls for the examination of the concept of third mission.

\subsection{The Evolution of the Role of Universities: A Brief Historical Overview}

Universities are long-standing social institutions. Over centuries several historical, social, cultural, political, economic, and environmental factors have influenced their development, leading to various roles for them. In the Middle Age, universities in Europe were part of the movement of restoration of the ancient culture, which started with schools born within cathedrals. This movement, originated under the patronage of the Church, ended up by overflowing from its initial field and by leading to the first "universitates", communities of teachers and students. The first universities in history (whose date of creation is set around the XII century) have appeared, ever since their birth, as a strong modernization element for medieval culture. Even if they were born in a social context that was strongly influenced by the Church, which sometimes encouraged their creation, they transformed one of the key principles of the medieval Christian philosophy, the finiteness of human knowledge and nature, in a strong element for progress.

If human nature is indeed imperfect, if its knowledge is transient and superficial, then it has to be possible to extend and enhance them by recovering the ancient science, as well as by improving the interpretation of holy writ. The objective of these institutions is, then, the transmission of truth and knowledge. Universities initially emerged in the Mediterranean area of Europe, with the exception of Oxford and Paris, that appear completely different. In Bologna and other Mediterranean universities, the university is mostly a clique of students who task themselves with finding a teacher, whom they will also remunerate. In the northern area, on the other hand, the university is prevalently based on teachers, to whom students are connected by trust and subordination relationships.

At the time, the university was born as an autonomous, private, and non-governmental institution. Soon enough, however, political and clerical powers acknowledged the importance of institutions that were able to attract students and professors from all over Europe. This is where certain actions come from, such as that by Federico II in the first of half of the XIII century, aiming on the one hand at 
stopping the "brain escape" to other universitates, and on the other hand at attracting professors and clerics by giving them several legal and economic immunities. This process was accentuated during the Renaissance, when universities that were "useful" to rulers were born, with their autonomy being progressively reduced in favor of a greater subjugation to governmental authorities: They then became tools to serve the public power and to educate the State's administrative workforce.

At the same time, universities lose their full control of scientific knowledge, and this loss is even deeper in the XVIII century, when academies, salons, literary groups, etc., rise to a greater importance. In the XIX century, a new era began for universities. While, during the first part of their history, the mission of universities was only teaching and they had to avoid being professionally defined as this would have limited their knowledge, a new idea of university emerges in the XIX century thanks to von Humboldt, founder of the Berlin University, according to which, along with the transmission of knowledge, the importance of research is underlined, i.e., the creation of knowledge.

This new idea identifies the specific feature of universities in the union between teaching and research. The student then becomes, from being the recipient of an educational process, the subject that educates himself through his own research path, under the supervision of the faculty. There is also a greater openness to applied sciences and professional studies, whose potential contribution to the development of society is acknowledged. The university is included in a national education system governed by the ministry, but it is largely autonomous, as is the faculty, whose independence is granted: According to von Humboldt, the State should not ask for anything of its universities, "anything that refers directly to itself, on the contrary it has to believe that, when they fulfil their specific objective, they also fulfil the State's needs, and indeed they do so in a broader way".

A third stage in the evolution of the idea of universities occurs in the XX century in the United States, and then spreads to other countries. The university in the US had distinguished itself since the XIX century, with respect to Europe, for a greater emphasis on broader access to education, which was seen as a key element in building the new democratic system, and for a greater attention toward agronomic and industrial sciences. Soon after the second world war, different factors contributed to a radical revolution in the education system: Demographic growth; the democratic push to improve life conditions thanks to science and technology; the process of massification of universities; the consideration that research had become a differentiated profession in its ends, and it was also more advanced, international homogenous and including a large number of people. In 1963, Kerr, dean of the Berkeley University, California, introduced the concept of multiversity [26], an idea of university that had to be able to ensure public policy goals through a general improvement of democratic processes and an increasing reduction in economic gaps within the social context.

Kerr's idea was to ensure a certain amount of economic autonomy to universities, also considering the greater expenses due to the increasing number of students. This is why he thought of a double economic support: One coming from steady public contributions, the other coming from research contracts with users that needed to employ the results of scientific investigation. Together with teaching and research, a third mission for universities emerged, and they were acknowledged in their ability to connect with their external environment, to understand its necessities and expectations, and to come up with appropriate answers to give society, in a continuous interchange.

\subsection{The New Role of Universities: A Literature Review}

Today's socio-economic reality is based on the concept of "knowledge", the element at the core of the currently dominating model of the knowledge-based economy and society $[3,27,28]$; in this sense, knowledge-intensive subjects, such as universities, become central to the economic development [29]. The first scholars that introduced this concept were Foray and Lundvall [30] during a workshop held by OECD in 1994. Although the term originates in the 1990s, the previous economic literature includes a specific array of models and perspectives that can be connected to this stream of thought, and within which three different streams can be identified.

The central role of knowledge in the economy first emerges in the '60s, during the birth of a new category of strongly innovation-oriented industries. This time was characterized by the propensity 
to find new occasions for development by employing knowledge, which allowed these sectors to grow, with positive consequences for the economy as a whole over the next three decades [31,32]. The acknowledgement of the possibilities emerging from the use of knowledge in the economy led the way for a second stream: In the 1990s, scholars focused on determining which sectors were knowledge-intensive, so that their identification would allow their development and lead to a massive increase in production $[33,34]$. Concerning the last stream, it focuses on managerial aspects related to the knowledge-economy binomial, studying the role of learning and continuous innovation in the firm $[35,36]$.

The attention toward knowledge was enhanced by global transformations in the economy and in society, such as the importance of intangible capital, i.e., human resources, education, and training, as well as the increase in the innovation rate in research and development. It becomes clear that economic growth and technologic progress, concerning the new theories on growth ("new growth theories"), are based on the power of knowledge [29], obtained through the elaboration of information.

This assumption can actually be easily recognized in the definition of knowledge-based economy, thus, introducing the concept of "human capital" as the starting point for the process of knowledge generation. Moreover, knowledge can be divided into tacit knowledge and explicit knowledge [37]. Tacit knowledge is tightly connected to the individual that has it and feeds it; it is knowledge that cannot be shared with others, unless it is made explicit and codified. Explicit knowledge, on the other hand, employs a standard language based on easy and straightforward concepts, which can be easily transferred by one individual to the other.

Abramowitz and David [38] claim that the process of knowledge codification, i.e., the step from tacit to explicit knowledge, has a central role in the economy, because it produces a "context-free" knowledge that can be used in a larger amount of settings. This would allow to enhance research, as stated by Leydesdorff [28]: "Knowledge itself can also be codified, and codified knowledge can, for example, be commercialized". The production of know-how, much like its codification, is the result of quantity and quality of human resources and of their geographic location. The "territory" variable can really enhance or discourage the creation of knowledge and, more importantly, scientific development.

The strong push toward the knowledge-based economy led to exploring the various ways through which know-how is produced and spread. The industrial sector has to continuously receive new codified knowledge to be able to innovate and grow. The activity that allows an effective exchange of knowledge from the producer to the user is called "technology transfer". According to Gibson and Rogers [39], technology transfer is the application of information (in the form of a technological innovation) into use. This definition does not consider the relationship dimension of technology transfer, an aspect highlighted by Feller et al. [40]: Research and technology transfer activities comprise an extended series of "interactive relationships that connect the functional activities of basic (disciplinary) research, applied (problem-solving) research, development, diffusion, adaptation, and dissemination into an overall technology delivery system". Levin [41], adding a social dimension to the definition, considers technology transfer as a socio-technical learning and development process, where the technology is perceived as a social construction where human choice and values influence the result. Finally, more recent definitions highlight the commercial aspect of knowledge. According to Power and McDougall [42], for example, technology transfer is the process by which technologies developed in universities are transformed into marketable products.

The initial and best-known theories on technology transfer were developed by Gibbons et al. [43]. Their studies created an actual innovation concerning the process of knowledge exchange, defined as the transition from "Mode 1" to "Mode 2": "knowledge production would be transforming from being a traditional science with no immediate outcomes for society (Mode 1) into a system that is open to those who use such science (Mode 2)", stressing that the good science is such if it is defined politically and commercially, and not academically by peer reviewing. Mode 1 was built by getting inspiration from the beliefs about the traditional role of universities, with them being inserted into a linear transfer model, the success of which depends on the equilibrium and the quality of hierarchical relationships between the actors in the exchange [44]. 
On the contrary, Mode 2 has incremental properties, which are aimed at overcoming previous limits such as the homogeneity of actors and the concentration in a specific academic field [43]. Despite the support of many scholars of Mode 2, such as Lee and Bozeman [45], who stated the importance of emerging research collaborations, this theory was harshly criticized. Criticisms were mainly directed to the innovative features introduced by the model. It seemed that claims concerning the contexts of application, heterogeneity, and transdisciplinarity, in the opinion of scientists, were vague, ambiguous, and hardly applicable [46]. However, these two methods do not comprise the whole group of theories and perspectives regarding technology transfer, although they are pioneers of more recent systems characterized by greater dynamisms and the orientation toward new growth perspectives.

The triple helix model, built by Eztkowitz and Leydesdorff in 1995 [47], for example, allowed to overcome certain imperfections that characterized existing approaches, such as the quasi-total lack of interaction between stakeholders, or the exclusion of some of them when carrying out the cognitive exchange. The triple helix completely changes the equilibria between actors in the technology transfer, who are all participants in today's knowledge-based society, giving a primary and innovative role to universities. This is in opposition both to Lundvall's national systems of innovation model, where the firm was the prevailing actor in the process, and to the triangle theory by Sábato [48], where the guiding role was fulfilled by the State [13].

The triple helix structure is obtained by combining the following: University-industrial sector-state, three elements that are connected, since they are part of the same process. Indeed, the key point of this new approach lies in the superposition and interchange of information and knowledge flows between the aforementioned entities, giving a relevant role to universities as the source of knowledge by definition.

Then, the triple helix model has evolved to include a fourth helix, represented by the "media-based and culture-based public" and the "civil society" [15], and a fifth helix, represented by the "natural environments of society" [16]. In the quadruple helix model, the territorial context and the civil society are seen as key drivers for spreading the benefits of research and development activities, in a democratic approach to innovation where government, business, academia, and civil participants work together to co-create the future. This approach goes beyond the concept of knowledge economy, including it in the wider perspective of the knowledge society and knowledge democracy. The quintuple helix Model, adding an ecologically sensitive perspective, stresses the need for a socio-ecological transition of society and economy, recognizing that the implementation of actions in sustainability could have a positive impact on the society as a whole. The importance of this approach was stressed by the European Commission [49] too, which identified the 'socio-ecological transition' as one of the major challenges for current and future societies and economies.

The emergence of the knowledge society and the implementation of the triple helix model have started an unprecedented renewal process for agents of technology transfer, mostly impacting the sphere of universities [23]. This has determined, over the last years, not only the new centrality obtained by the academia, but also numerous changes inside it.

These changes have, thus, had effects on the primary mission of universities. The role that they have, in this modern perspective, refers to the concept of "third mission" [23,46,50], a symbol of their involvement in socio-economic progress. The triple helix model itself clearly recognizes the great relevance that these institutions have, institutions acting with the goal of planning the social and technologic progress [16]. This is, therefore, a metamorphosis that ends up in a full transformation of the appearance of universities in their environments. This is showed by the distancing from the idea that described universities as "ivory towers" [51]. Universities, in fact, give up their self-referred behavior, which was always one of their defining features, to implement more proactive strategies: All this is only possible through the engagement and collaboration with other actors that deal with research.

This new role, which from now on will be called "third mission", has been defined in several ways, presented in Table 1. 
Table 1. Different definitions of the new role of universities.

\begin{tabular}{|c|c|c|c|}
\hline Author(s) (year) & Source & Concept & Definition \\
\hline $\begin{array}{c}\text { Molas-Gallart et } \\
\text { al. [52] }\end{array}$ & $\begin{array}{l}\text { Science and Technology } \\
\text { Policy Research }\end{array}$ & $\begin{array}{l}\text {-Third Stream } \\
\text {-Third Leg }\end{array}$ & $\begin{array}{l}\text { Third Stream/Leg activities "are concerned } \\
\text { with the generation, use application and } \\
\text { exploitation of knowledge and other } \\
\text { university capabilities outside academic } \\
\text { environments" (p. iv). }\end{array}$ \\
\hline $\begin{array}{c}\text { Gunasekara } \\
\text { [53] }\end{array}$ & $\begin{array}{c}\text { Journal of Technology } \\
\text { Transfer }\end{array}$ & $\begin{array}{l}\text {-Third Role } \\
\text {-University engagement }\end{array}$ & $\begin{array}{l}\text { "Third role [is] performed by universities in } \\
\text { animating regional economic and social } \\
\text { development" (p. 102). } \\
\text { "The universities engagement approach } \\
\text { points to a developmental role performed } \\
\text { by universities in regional economic and } \\
\text { social development that centres on the } \\
\text { intersection of learning economies and the } \\
\text { regionalisation of production and } \\
\text { regulation" (p. 103). }\end{array}$ \\
\hline $\begin{array}{l}\text { Pilbeam } \\
\text { [54] }\end{array}$ & $\begin{array}{l}\text { Journal of Higher } \\
\text { Education Policy and } \\
\text { Management }\end{array}$ & -Third stream income & $\begin{array}{l}\text { "Revenues from the commercial } \\
\text { exploitation of university intellectual assets } \\
\text { (third stream income)" } \\
\text { (p. 297). }\end{array}$ \\
\hline $\begin{array}{c}\text { Business/Higher } \\
\text { Education Round } \\
\text { Table } \\
\text { [55] }\end{array}$ & & $\begin{array}{l}\text {-Community } \\
\text { Engagement } \\
\text {-Third mission }\end{array}$ & $\begin{array}{l}\text { "Communities engagement has a broad } \\
\text { vista that extends beyond business and } \\
\text { economic aspects. Universities have a } \\
\text { wider view of engagement which includes } \\
\text { social, economic, environmental and } \\
\text { cultural dimensions of capacity building" } \\
\text { (p. 3). } \\
\text { "Third Mission activities of universities seek } \\
\text { to generate, apply and use knowledge and } \\
\text { other university capabilities outside } \\
\text { academic environments" (p.4). }\end{array}$ \\
\hline $\begin{array}{l}\text { HEFCE } \\
{[56]}\end{array}$ & & -Third Stream & $\begin{array}{l}\text { "Third Stream refers to work to increase the } \\
\text { impact of higher education on economic } \\
\text { development and the strength and vitality } \\
\text { of society as a third stream of activity } \\
\text { alongside, and complementary to, teaching } \\
\text { and research" (p. 26). }\end{array}$ \\
\hline $\begin{array}{l}\text { Webber and Jones } \\
\text { [57] }\end{array}$ & $\begin{array}{l}\text { Journal of Higher } \\
\text { Education Policy and } \\
\text { Management }\end{array}$ & $\begin{array}{l}\text {-Third constituent of } \\
\text { higher education }\end{array}$ & $\begin{array}{l}\text { "Third constituent of higher education can } \\
\text { be described as consisting of universities' } \\
\text { relations with and contributions to other } \\
\text { sectors of society" (p. 17). }\end{array}$ \\
\hline $\begin{array}{c}\text { Bornmann } \\
\text { [58] }\end{array}$ & $\begin{array}{l}\text { Journal of the American } \\
\text { Society for Information } \\
\text { and Science Technology }\end{array}$ & $\begin{array}{c}\text {-Societal impact of } \\
\text { research }\end{array}$ & $\begin{array}{l}\text { "Societal impact of research is concerned } \\
\text { with the assessment of social, cultural, } \\
\text { environmental, and economic returns } \\
\text { (impact and effects) from results (research } \\
\text { output) or products (research outcome) of } \\
\text { publicly founded research" (p. 217). }\end{array}$ \\
\hline $\begin{array}{l}\text { Sánchez-Barrioluengo } \\
\text { [59] }\end{array}$ & Research Policy & $\begin{array}{l}\text {-Social and Business } \\
\text { Engagement }\end{array}$ & $\begin{array}{c}\text { "Social and Business Engagement is seen as } \\
\text { reflecting the changing nature of scientific } \\
\text { knowledge and the natural tendency for } \\
\text { academia to adapt in response to social } \\
\text { changes" (p. 2). }\end{array}$ \\
\hline $\begin{array}{l}\text { Watson and Hall } \\
\text { [60] }\end{array}$ & $\begin{array}{l}\text { International Journal of } \\
\text { Academic Research in } \\
\text { Management (IJARM) }\end{array}$ & -Third Stream & $\begin{array}{l}\text { "Third Stream agenda is a critical strategy } \\
\text { in the pursuit of enriched learning, } \\
\text { enhancing student employability and much } \\
\text { needed revenues" (p. 48). }\end{array}$ \\
\hline $\begin{array}{c}\text { Guerrero et al. } \\
{[61]}\end{array}$ & Research Policy & -Third Mission & $\begin{array}{l}\text { "The entrepreneurial university serves as a } \\
\text { conduit of spillovers contributing to } \\
\text { economic and social development through } \\
\text { its multiple missions of teaching, research, } \\
\text { and entrepreneurial activities" (p. 748). }\end{array}$ \\
\hline
\end{tabular}

Source: own elaboration. 
The university receives a new definition, which is in line with the studies by Ernest Boyer [62]. In fact, many authors state that he was one of the first that investigated the directional change that occurred in higher education institutions, which pushed them to take responsibility toward their community [57]. This opened a window in the walls of academia, allowing them to direct their success toward the outside as well.

Etzkowitz [51] and Leydesdorff [63] state that the university reform that was described so far created "Hybrid Universities", that can be observed in various forms, such as "academic Spin-offs". Today, universities are going toward a greater openness to practically applying and commercially exploiting the technology they create [64], which is why they are called "entrepreneurial universities" [65]. The entrepreneurial university model takes into account various conditions, that are applied differently in each cultural environment: (a) The approach to operational and strategic choices is an entrepreneurial one; (b) connections with the external environment (society, institutions, the economy) are created and managed with an entrepreneurial approach; (c) professors, researchers, and students act in an entrepreneurial way. In the US, this model of university emerged in a bottom-up way, while in Europe the "academic entrepreneurship" phenomenon is recent and is following a top-down path, induced by the need to close the innovation gap between these two geographical areas.

In this context, performance management and performance measurement represent tools by which universities could obtain approval from their stakeholders [66]. So, higher education institutions, similar to private organizations, start to be evaluated on the basis of their achieved performance that is wider, including teaching, research, and third mission.

\subsection{Intellectual Capital and the Third Mission: A Literature Review}

Given the decline of financial resources, intangible resources appear more stable, able to generate the competitive differential of universities, and improve their social legitimacy $[67,68]$. The term "intangible assets" could be used with the same meaning of intellectual capital [69], defined as "intellectual material, knowledge, experience, intellectual property, information that can be put to use to create value" [25]. As the authors explain, the concept of value is broader than mere monetary wealth creation, and goes to include social value, which is one of the outputs of the university's activities, as well as one of the pillars of the third mission theory. According to Glewwe [70] and Drucker [71], to higher levels of education correspond higher levels of economic growth, so governments have to reorganize the national education system, by ensuring the development of intellectual capital [72]. Intellectual capital has a critical role in universities, where any kind of activity is strictly connected to develop and transmit knowledge [73,74]; consequently, every education institution is called to consider and asses its own intellectual capital.

In the past decade, various approaches for the use of an intellectual capital perspective were developed: The RICARDIS document, proposed by the European Commission, states the key role of intellectual capital in the knowledge economy, even if it is typically associated with private companies. More recent studies [75] show the central role of intellectual capital also for public entities and, of course, for public universities; consequently, the focus on it in higher education is increasing.

The majority of contributions on this topic is from Europe, especially from Italy and Spain, because the central governments of these two countries have decided to assign financial resources on the basis of the performance achieved by public universities [76,77]. So, according to Di Bernardino and Corsi [78], there is a need to re-interpret the results achieved by universities in terms of social and economic value created (third mission outcomes). A strong interest in IC practices could be seen as a manifestation of the strategic approach adopted by universities, especially when they try to attract further students, researchers, and funders; in this sense, IC components represent strategic tools, useful for achieving the university's mission and vision [79].

Skills and knowledge of human resources, the knowledge encoded within the organization, and processes that derive from external relations generate a system of strategic resources for higher education institutions, identified as ICU $[80,81]$. The consideration of ICU (and intangible resources 
in general) is currently sporadic and not institutionalized, except for Austrian universities, which, in 2006, adopted mandatory knowledge balance sheets for the first time (according to the "Intellectual Capital Report 1999-2004"). In Italy and Spain, the adoption of descriptive reports of ICU is completely voluntary [82-84], and other experiences in ICU disclosure practices are present in Eastern Europe [85]. Several authors see ICU as a communication tool for social legitimating purposes [86] or as appropriate means to foster discussion about the correct exploitation of resources and the adequacy of goals, but sometimes universities remain reluctant to adopt these tools, due to the lack of an adequate reward system [87]. According to Dumay [85], if universities use and upgrade their IC without adopting reporting models, they will not achieve their social legitimacy.

In this sense, different aspects of IC could be associated with university performance. Human capital is a fundamental part of university IC, it represents the knowledge, skills, and ability of all the subjects who offer their contribution within the organization, such as teachers, researchers, managers, administrative staff, and students in general $[24,74,77,88,89]$. In particular, the IC of professors and researchers is represented by their teaching and research competencies. Martin-Sardesai and Guthrie [90] explain the consequences of university performance measurement system for academic human capital, by showing that measuring academic research in a predefined manner is not correct to assess the academic performance.

Generally, the structural capital refers to the organizational culture, routines, products, and capabilities, so it is the backbone that supports IC within the organization [91-94]; in universities, it is represented by the knowledge deriving from internal processes.

Relational capital is linked to the building of relationships between a specific organization and its environment $[93,95]$, that provides a knowledge increase for the organization [91]; it is represented by the interactions that universities have with external subjects, always in a third mission perspective.

According to Secundo et al. [8], intellectual capital should be measured and managed in order to enhance the strategic management of universities: The authors built the "intellectual capital maturity model" (ICMM), which proposes a "staged framework to initiate a step-by-step change within a university based upon its current level of IC management maturity". It is a flexible framework, used to define and implement IC measurement and management approaches as a part of the strategic behavior of universities, in order to ensure quality in their activities. Since intellectual capital represents the largest proportion of universities' assets, its effective management is a key issue in university policy [8]; this consideration also leads to the need of measuring it in terms of its direct or indirect social value $[2,96]$.

Moreover, given the complexity of measuring the performance of universities in terms of third mission activities, intellectual capital can provide help "to identify structural and personal strengths and weaknesses, reveal the current state of the accomplishment of university's third mission and can be used as an assessment instrument" [2]. The links between IC, the entrepreneurial university, and the third mission can be further expanded to include the similarity between the fourth-stage IC perspective and the third mission perspective, especially concerning the creation of knowledge with an ecosystem focus [10]. As previously mentioned, this approach can be useful for managing third mission variables.

Over the years, universities have faced an increased demand for transparency regarding their use of public resources, and issues related to the need of disclosing have been debated along the second and third stages of IC research [97]. According to the fourth stage of IC perspective, instead, specific indicators could be more appropriate in order to show the monetary, ethical, social, and environmental impact generated by the organization [98]. This is because traditional financial measures show nothing about how well an organization is operating to enhance IC.

In this sense, managing IC could be fundamental to achieve the third mission [8], benefits for university performance [99], changes in governance and accountability mechanisms [100], and a communicative culture about the monetary, social, and environmental impact of the education institutions [98] But, besides the exploitation of intellectual capital as a useful tool to manage and assess 
university third mission, several frameworks have been used to investigate the different dimensions of this new role.

Indeed, following the diffusion of the third mission of universities at the international level, the OECD carried out studies on this topic, which mainly tried to define this worldwide phenomenon. The results of these studies were then presented during the UNESCO workshop in 2007 [101].

Thanks to the joint effort by several countries and by the 12 European teams leading the study, different categories of actions falling in the field of third mission were suggested, such as: Human resources, intellectual property, spin-offs, contracts with industry, contracts with public bodies, participation into policy making, involvement into social and cultural life, public understanding of science [101]. The E3M project, on the other hand, limited the intervention areas of the third mission to three sectors: Technology transfer and innovation, continuing education, social engagement. In the next sections, these topics will be analyzed more in depth, describing the indicators that were suggested at the international level to analyze them.

\section{Methodology}

The methodology employed for answering our research questions is qualitative: Following an overview of the literature on third mission and intellectual capital, we carried out a documentary analysis of ranking systems and research projects regarding third mission activities implemented by universities. Once this state-of-the-art framework is in place, we analyze a case study describing the approach adopted in Italy in the evaluation of third mission activities. Data were collected through unstructured interviews with officers of the Italian National Agency for the Evaluation of the University and Research Systems (ANVUR), then analyzed on the basis of the findings presented in Sections 4.1 and 4.2 , which serve as a comparative framework against which the Italian case is explained.

\section{Findings}

The growing importance of third mission in universities has led institutions and researchers to look for indicators to assess this dimension. The need to evaluate these activities not only comes from the recognition that indicators could allow universities to understand their performance and foster accountability and improvement of management practices, providing effective value to society, but also from the greater emphasis put by governments on quality assurance in universities, which started from the experience of the Research Assessment Exercise, launched in Great Britain in 1996, and was followed by the creation, in many countries, of analogous evaluation systems.

However, while commonly accepted evaluation and ranking systems for the two traditional missions of the university now exist, it is only recently that authors have started elaborating such frameworks. Secundo et al. [24] build on the fourth-stage IC perspective and on the theory of collective intelligence to create a framework for evaluating the three missions of universities in an IC perspective. Concerning the third mission, the authors suggest a comprehensive set of indicators for each of the processes within third mission activities, based on the E3M and other projects on third mission, and then expanded according to further considerations on IC. Despite several initiatives in this direction, the collection of data and the development of indicators on third mission activities still has many limitations. This is mainly due to [102] the nature of data needed to track these activities, often regarded as invisible, unquantifiable, informal, and not available in university units, and the dependence on contextual factors for the development of such activities, which could make comparisons problematic.

In general terms, it is possible to state that information generally used to evaluate and rank universities could come from different sources:

- Independent third parties: Many data are collected by government agencies and grant-making bodies and they very often have a financial nature;

- Surveys: Universities' stakeholders may be asked to answer questions on many aspects of the higher education system, providing comparable data on educational quality; 
- Research databases: Information on the quality of research activities carried out by universities can be collected from the most largely used research databases, such as Scopus and Web of Science;

- University: When important indicators on quality cannot be obtained in the former ways, data can be collected by asking the university itself to answer a questionnaire; they are often the most complete and accurate source of information;

- Other sources: Some national rankings use information on research funds, prizes, and awards, etc.; such data are often not comparable across countries, so they are rarely used at international level.

This section will first examine the main international ranking systems, analyzing the extent to which they include an assessment of third mission activities; it will then investigate the main international research projects aimed at identifying comprehensive indicators for these activities; finally, it will focus on the Italian evaluation system, which included third mission as a dimension to be measured and evaluated in higher education institutions.

\subsection{International Rankings}

A ranking is a relationship between a set of items such that, for any two items, the first is either 'ranked higher than', 'ranked lower than', or 'ranked equal to' the second [103]. University rankings have become important worldwide, becoming a significant factor impacting on higher education institutions, policy makers, public opinion, and media $[102,104]$. They can be used by students and their families when making choices about where to study, by the universities themselves to benchmark their performance against their competitors and to adopt subsequent choices, and by decision makers when allocating resources. However, they are often criticized, since they have evolved from being a semi-academic exercise to an international business, with significant commercial and consultancy opportunities and substantial influence [104].

Several global university rankings are [105] the academic ranking of world universities (ARWU, also known as "Shanghai rankings"), the QS (Quacquarelli Symonds Limited) world university rankings, and the Times higher education world university rankings (THE). To rank world universities, they use a set of different indicators, summarized in Table 2.

As Table 2 shows, the ARWU, first published in 2003 by the Shanghai Jiao Tong University, only relies on publicly accessible data; the QS and the THE, launched in 2004 as a unique ranking and after 2009 published separately, derive much information from reputation surveys and data gathered from the universities themselves. Among the three, only the THE considers a dimension related to third mission, industry income, which assesses a university's knowledge-transfer activity by looking at how much research income it earns from industry, scaled against the number of academic staff it employs. Despite the recognition of the importance of academia's relations with the external environment, the weight on the total is very low $(2.5 \%)$ and the focus is only on university-industry collaborations.

The three rankings mentioned above have been strongly criticized, since they compare different types of higher education institutions using a single set of criteria [104].

To overcome some of these limitations, in the last few years, A several other rankings have been proposed. The most important is the U-Multirank (UMR), a multi-dimensional ranking of higher education institutions launched by the European Commission following a feasibility study by Van Vught and Ziegele [106]. It is aimed at moving beyond the research focus of other rankings and performance indicators [107] and at overcoming the prescriptive nature of classification systems by enabling the user to choose the most appropriate comparators [104]. Table 3 shows UMR's dimensions and data collection tools. Each dimension includes a set of indicators. 
Table 2. Major international universities rankings.

\begin{tabular}{|c|c|c|}
\hline Name of the Ranking & Indicators & Data Source \\
\hline \multirow{6}{*}{$\begin{array}{l}\text { Academic Ranking of } \\
\text { World Universities } \\
\text { (ARWU) }\end{array}$} & 10\% Alumni winning Nobel Prizes and Fields Medals & Nobel Prize database \\
\hline & $20 \%$ Staff winning Nobel Prizes and Fields Medals & List of Fields medalists \\
\hline & $20 \%$ Highly cited researchers in 21 broad subject categories & $\begin{array}{l}\text { Highly Cited Researchers } \\
\text { database }\end{array}$ \\
\hline & $\begin{array}{l}\text { 20\% Papers published in Nature and Science (except for } \\
\text { institutions specialized in humanities and sciences, for } \\
\text { which this indicator is not considered, and the relative } \\
\text { weight is relocated to other indicators) }\end{array}$ & \multirow[t]{2}{*}{ Web of Science database } \\
\hline & $\begin{array}{l}\text { 20\% Papers indexed in Science Citation Index-expanded and } \\
\text { Social Science Citation Index }\end{array}$ & \\
\hline & $\begin{array}{c}10 \% \text { Per capita academic performance (weighted scores of } \\
\text { the above five indicators divided by the number of full-time } \\
\text { equivalent academic staff) }\end{array}$ & National agencies \\
\hline \multirow{6}{*}{$\begin{array}{l}\text { QS World University } \\
\text { Rankings }\end{array}$} & $40 \%$ Academic reputation & Global peer review survey \\
\hline & $10 \%$ Employer reputation & Global survey \\
\hline & $20 \%$ Student-to-faculty ratio & University data \\
\hline & $20 \%$ Citations per faculty & Scopus database \\
\hline & $5 \%$ International faculty ratio & \multirow{2}{*}{ University data } \\
\hline & $5 \%$ International students ratio & \\
\hline \multirow{5}{*}{$\begin{array}{l}\text { Times Higher Education } \\
\text { World University Rankings } \\
\text { (THE) }\end{array}$} & $\begin{array}{c}\text { Teaching (the learning environment) } \\
15 \% \text { Reputation survey } \\
4.5 \% \text { Staff-to-student ratio } \\
2.25 \% \text { Doctorate-to-bachelor's ratio } \\
6 \% \text { Doctorates awarded-to-academic staff ratio } \\
2.25 \% \text { Institutional income }\end{array}$ & $\begin{array}{l}\text { Global survey } \\
\text { University data }\end{array}$ \\
\hline & $\begin{array}{c}\text { Research (volume, income, and reputation) } \\
18 \% \text { Reputation survey } \\
6 \% \text { Research income } \\
6 \% \text { Research productivity }\end{array}$ & $\begin{array}{l}\text { Global survey } \\
\text { University data } \\
\text { Scopus database }\end{array}$ \\
\hline & $\begin{array}{l}\text { Citations (research influence) } \\
30 \% \text { Citation impact }\end{array}$ & Scopus Database \\
\hline & $\begin{array}{l}\text { International outlook (staff, students, research) } \\
2.5 \% \text { International-to-domestic-student ratio } \\
2.5 \% \text { International-to-domestic-staff ratio } \\
2.5 \% \text { International collaboration }\end{array}$ & $\begin{array}{l}\text { University data } \\
\text { Scopus Database }\end{array}$ \\
\hline & $\begin{array}{l}\text { Industry income (knowledge transfer) } \\
2.5 \% \text { Income from industry }\end{array}$ & University data \\
\hline
\end{tabular}

Table 3. U-Multirank.

\begin{tabular}{cc}
\hline Dimensions & Data Source \\
\hline General & Self-reported data \\
\hline Teaching and Learning & $\begin{array}{c}\text { Self-reported data } \\
\text { Student surveys }\end{array}$ \\
\hline Research & Self-reported data \\
Bibliometric and patent data
\end{tabular}

Source: own elaboration. 
Differently from the above-mentioned university rankings, the UMR does not produce a combined, weighted score across the different areas of performance; moreover, it only compares institutions with similar activity profiles. Concerning the third mission, the UMR considers not only the dimension related to technology and innovation (in the knowledge transfer area), but also its social dimension (in the regional engagement and in the international orientation areas).

Therefore, the weight of third mission activities in the main international rankings is marginal or non-existent, which means that these networks cannot be used to evaluate or compare institutions or countries on the basis of this dimension.

\subsection{International Research Projects}

Besides international rankings, in the last decade, many research projects have attempted to identify and test indicators for third mission activities.

Among others, a report commissioned by the Russell Group of Universities was aimed at providing an analytical framework and a comprehensive set of indicators that may assist in the tracking and management of university third stream activities [52]. They identified 12 groups of third stream activities (technology commercialization, entrepreneurial activities, advisory work and contracts, commercialization of facilities, contract research, collaboration in academic research, staff flow, student placement, learning activities, curriculum alignment, social networking, non-academic dissemination), defined as those engaging or targeting non-academic communities, and for each of them they developed a set of indicators, representing measures of knowledge transfer to the wider community. Concerning data sources, information could be collected from university's offices and documents, as well as through surveys. The authors of this study recommend focusing on indicators of third-stream activities, instead of analyzing their outcomes or impact. This is mainly because of three reasons: The impact of academic research is long-term; there could be a halo effect, due to the fact that impact measures may be biased because academic work that gains visibility tends to receive additional attention just because of this visibility; and 21non-academic communities are often beyond universities' control and knowledge.

The Observatory of European University (OEU), carried out in the framework of the PRIME Network of Excellence, was aimed at developing a common framework for the characterization of research activities undertaken in universities, gathering data under different institutional conditions [108]. The final objective was to provide universities with a benchmark for comparisons with similar universities, using measures of their activities related to funding patterns and costing structures, human resources, academic outcome, third mission, governance, and strategy. In this project, third mission, defined as the mission encompassing the relations between a university and its non-academic partners, includes two main dimensions: The economic dimension focuses on human resources, intellectual property, spin-offs, and contracts with industry; the societal dimension takes into consideration the public understanding of science, involvement in social and cultural life, participation in policy-making, and contracts with public bodies. For these dimensions, a total of 36 indicators (or groups of indicators) were proposed. Concerning sources of data, they could be internal (annual reports or other university documents, self-reported data), or external (statistical surveys, patent office data, research databases, and various national surveys); however, the scarcity of third mission data is recognized [108].

The higher education-business and community interaction (HE-BCI) survey is an annual study conducted by the Higher Education Funding Council for England (HEFCE), which examines the exchange of knowledge between universities and the wider world, informing the strategic direction of "knowledge exchange" activity that funding bodies and higher education institutions in the United Kingdom undertake. The annual report, whose first edition was published in 2001, provides information on a range of activities, from the commercialization of new knowledge, through the delivery of professional training, consultancy, and services, to activities intended to have direct social benefits. In particular, institutions are asked to answer a questionnaire on the following issues: 
Strategy; infrastructures; research-related activities; intellectual property; social, community, and cultural engagement; regeneration; business and community services; education and continuing professional development.

The E3M Project (European indicators and ranking methodology for university third mission) was a three-year project co-funded by the European Commission and developed by partners from eight European countries. The aim was to generate a comprehensive instrument to identify, measure, and compare third mission activities, creating indicators and proposing a new approach on the concept of ranking methodologies. In order to achieve consensus on the set of indicators, the Delphi methodology [109-112] was applied. At the end of the process, 54 indicators were identified for the three main dimensions of third mission: Continuing education (18 indicators), technology transfer and innovation (20 indicators), and social engagement (16 indicators). Institutional data are the main source of information, followed by survey data, bibliometric data, public datasets, and concerning continuing education, program lists as well as program folder and websites.

Finally, in 2012, the European Commission and the OECD provided a framework to help European higher education institutions manage and drive the institutional and cultural changes needed by their new mission in society and the economy, with a focus on their entrepreneurial role, analyzing different dimensions of third mission activities, although they do not explicitly refer to it. This framework, which attempts to reflect the diverse characteristics of the Entrepreneurial University [50,113-115], is intended as a self-assessment tool, guiding universities to identify their strengths and weaknesses, as well as potential areas of development, in terms of innovation in research, knowledge exchange, teaching and learning, governance, internationalization, and relations with the wider regional, social, and community environment [1]. Table 4 synthetizes the major university research projects, by underling are the main dimensions analyzed.

To conclude, despite the many efforts, we are far from finding an agreement on a set of indicators and methodologies to evaluate quality in third mission activities, which could promote the creation of clear and comparable datasets.

\subsection{The Italian Case}

The report of the E3M Project stated that "each country operates in contexts which define its own good practices. A global best practice for third mission does not exist. Each country-and each university-finds its own solutions" [102].

In Italy, the evaluation of third mission activities is assigned to ANVUR, the Italian National Agency for the Evaluation of the University and Research Systems. In its 2004-2010 evaluation of research quality (VQR), it had already put in place a process to analyze how universities performed in terms of third mission, by identifying key indicators and providing a broad definition based on the degree of openness towards the socio-economic context.

The aim is to evaluate the quality in higher education, but there is no a common agreement on the meaning of this concept that could be perceived as the universities' capacity to meet the expectations of their stakeholders, the ability to achieve their missions or objectives, or in terms of return on investment. The 2004-2010 VQR Call defined eight third mission indicators, some of them connected to activities aimed at economic enhancement of knowledge (research and consultancy contracts with external clients, patents, creation of spin-off ventures, participation of incubators and consortia with technology transfer aims), and others connected to knowledge enhancement for the wellbeing of society (managing archaeological sites and museums, and other third mission activities). They are presented in Table 5. 
Table 4. Major international university research projects.

\begin{tabular}{|c|c|c|c|}
\hline Name of the Project & Project's Commissioner & Main Dimensions Analyzed & Data Source \\
\hline $\begin{array}{c}\text { Measuring Third Stream } \\
\text { activities }\end{array}$ & $\begin{array}{l}\text { Russell Group of } \\
\text { Universities }\end{array}$ & $\begin{array}{l}\text { Technology commercialization, } \\
\text { entrepreneurial activities, advisory work } \\
\text { and contracts, commercialization of } \\
\text { facilities, contract research, collaboration in } \\
\text { academic research, staff flow, student } \\
\text { placement, learning activities, curriculum } \\
\text { alignment, social networking, } \\
\text { non-academic dissemination }\end{array}$ & $\begin{array}{c}\text { University documents, } \\
\text { self-reported data, surveys }\end{array}$ \\
\hline $\begin{array}{c}\text { Observatory of European } \\
\text { University }\end{array}$ & $\begin{array}{l}\text { PRIME Network of } \\
\text { Excellence }\end{array}$ & $\begin{array}{l}\text { Human resources, intellectual property, } \\
\text { spin-offs and contracts with industry, } \\
\text { public understanding of science, } \\
\text { involvement in social and cultural life, } \\
\text { participation in policy-making and } \\
\text { contracts with public bodies }\end{array}$ & $\begin{array}{l}\text { Annual reports or other } \\
\text { university documents, } \\
\text { self-reported data, statistical } \\
\text { surveys, patent office data, } \\
\text { research databases and } \\
\text { various national surveys }\end{array}$ \\
\hline $\begin{array}{c}\text { Higher } \\
\text { Education-Business and } \\
\text { Community Interaction } \\
\text { survey }\end{array}$ & $\begin{array}{l}\text { Higher Education } \\
\text { Funding Council for } \\
\text { England }\end{array}$ & $\begin{array}{l}\text { Strategy; infrastructures; research-related } \\
\text { activities; intellectual property; social, } \\
\text { community and cultural engagement; } \\
\text { regeneration; business and community } \\
\text { services; education and continuing } \\
\text { professional development }\end{array}$ & Self-reported data \\
\hline $\begin{array}{c}\text { European Indicators and } \\
\text { Ranking Methodology } \\
\text { for University Third } \\
\text { Mission }\end{array}$ & European Commission & $\begin{array}{l}\text { Continuing education, technology transfer } \\
\text { and innovation, social engagement }\end{array}$ & $\begin{array}{c}\text { Institutional data, surveys, } \\
\text { bibliometric data, public } \\
\text { datasets, university and } \\
\text { programs documents }\end{array}$ \\
\hline $\begin{array}{l}\text { A Guiding Framework } \\
\text { for Entrepreneurial } \\
\text { Universities }\end{array}$ & $\begin{array}{c}\text { European Commission } \\
\text { and OECD }\end{array}$ & $\begin{array}{l}\text { Innovation in research, knowledge } \\
\text { exchange, teaching and learning, } \\
\text { governance, internationalization, and } \\
\text { relations with the wider regional, social, } \\
\text { and community environment }\end{array}$ & $\begin{array}{l}\text { Self-assessment } \\
\text { questionnaire }\end{array}$ \\
\hline
\end{tabular}

Source: own elaboration.

Table 5. Third mission indicators-2004-2010 evaluation of research quality (VQR) call.

\begin{tabular}{cc}
\hline & \multicolumn{1}{c}{ Third-parties' activities } \\
\cline { 2 - 2 } $\begin{array}{c}\text { Third Mission activities for the economic } \\
\text { enhancement of knowledge }\end{array}$ & Patents \\
\cline { 2 - 2 } & Spin-offs \\
\hline & Concubators \\
\hline \multirow{2}{*}{ Third Mission cultural and social activities } & Museums \\
\cline { 2 - 2 } & Archaeological sites \\
\hline
\end{tabular}

Source: Own elaboration.

The results of the 2004-2010 VQR, presented in a report [116], highlight data that confirm the strong academic commitment to carry out third mission activities, stressing the heterogeneity of the examined elements. These operations, in fact, are difficult to be quantified because of their nature. In addition to this, the level of difficulty in obtaining this information depends on the experience of universities in managing data regarding these dimensions.

The choice by ANVUR to create the "other third mission activities" categories signaled its intent not to exclude from evaluation processes all those operations promoted by universities that could be considered as part of the third mission but that did not fall into any other category. Some examples are the following: The placement of students and graduates; networking and planning events that facilitate local development projects with socio-cultural aims; the establishment of partnerships and agreements with external institutions, etc. However, the large amount of activities in these categories ( $56 \%$ of which came from one university, the University of Bologna) requested to find new indicators or to better explain what the existing ones meant. 
This consideration, along with the need to overcome a merely quantitative evaluation of third mission activities, as well as to adapt to new regulations (Decreto Legislativo n. 19/2012, which defined the principles of the system of self-evaluation, periodical evaluation and validation, and the Decree by the Minister for Education, University and Research n.47/2013, which included the third mission among institutional activities whose evaluation is mentioned in the Periodical evaluation report that must be sent to the MIUR by the 31st of July of each year), led to redefining the criteria to evaluate the third mission in Italy. These criteria merged into the manual for the evaluation of the third mission [117], which describes the new procedures and the new indicators, which include both research-enhancing activities (patents, spin-offs, contracts with third parties and conventions, intermediaries) and the activities that produce social and cultural public goods (public engagement, cultural assets, continuous education, clinical experiments). Information on these indicators shall be included each year in the "Scheda Unica Annuale della Ricerca Dipartimentale" (SUA-RD). Table 6 synthetizes these new procedures and indicators.

Table 6. Third mission indicators-manual for the evaluation of the third mission.

\begin{tabular}{cc}
\hline \multirow{2}{*}{ Research enhancing Third Mission activities } & Patents \\
\cline { 2 - 2 } & \multicolumn{1}{c}{ Spin-offs } \\
\cline { 2 - 2 } Third Mission indicators concerning the \\
production of social and cultural public goods & Public engagement \\
\cline { 2 - 2 } & Cultural assets \\
\cline { 2 - 2 } & Continuous education \\
\hline
\end{tabular}

Source: own elaboration.

According to the new 2011-2014 VQR Call (D.MIUR n.458/2015), the evaluation of the third mission must be carried out on the basis of the guidelines from the manual. This evaluation will be based on informed peer review, which combines the analysis of indicators and the expert rating. In particular, a commission of experts, created for this purpose, will have the data and indicators on hand in the SUA file, and will be able to meet the manager of each structure to better understand essential elements of third mission activities and of the related third mission strategy. As is stated by the 2011-2014 VQR, the commission will have to provide a qualitative evaluation for each of the eight areas, along with a merit ranking.

The difference from the previous experience, thus, is that the evaluation of third mission is no longer based on the "product" and realized by adding quantitative values for each indicator-it is now based on the "process". This will make it possible to obtain a standardized and comparable database on all Italian universities.

One of the most relevant stakeholders for Italian state universities is MIUR, which plays both the role of the main investor and that of the external manager by providing guidelines and standards that should be respected. Other stakeholders ask fragmented information that could regard the scientific results obtained, the quality of teaching, or the social implications generated by the knowledge that university shares with the society. In this sensem the ICU perspective and the quality evaluation system can satisfy the needs of different subjects simultaneously, inspired by the principles of the collaboration and co-creation of value (fourth-stage IC perspective).

In this sense, the Italian VQR approach, especially in the second model (2011-2014 VQR) tries to analyze the efficiency, the effectiveness, and the value of research activities and third mission through qualitative and quantitative indicators related to each component of IC. Indeed, IC could be split in human, structural, and relational capital [118]: Human capital refers to knowledge, skill, 
innovation, and the ability developed by individuals within the university, such as teachers, researchers, administrative staff, and students in general [24,74]; structural capital represents the organizational culture, including organizational routines, processes, and technological components [74,119-121]; relational capital regards all the relations between an organization and its environment $[93,95]$. While structural capital could be evaluated through patents, licenses, publications, databases, and process of management [78], relational capital could be assessed through indicators such as contracts from third parties or incubators.

\section{Discussion and Conclusions}

For a long time, universities focused on what is called basic research: The "pure" researcher, sitting in his ivory tower, pursued scientific progress in isolation, without thinking of engaging in actual activities that could create economic value. Today, the scenario has completely changed: Over the last years, society and economy have challenged the university to use its knowledge in applied research, even in those areas that are less inclined to question the social utility of theoretical material originating from the academia. Indeed, in the current socio-economic scenario, widely influenced by the recent financial crisis and by the shift towards the knowledge economy, higher education institutions are at the forefront of change towards an enhanced model of development based on closer industry-government-society relationships.

The evolution of the role of universities also has interesting consequences in terms of intellectual capital theories: Given the increased focus on the social and economic value created by universities, there is greater space for intertwining such considerations with the management and measurement of their intellectual capital, able to provide information about the third mission performance achieved. In this sense, while international rankings (analyzed in Section 4.1) resulted as inappropriate, by associating with the third mission activities a weight that is marginal or not existent, and international projects (Section 4.2) are not able to provide a set of indicators or methodologies to evaluate quality in third mission, intellectual capital could be seen as a solution. Indeed, as seen before, the third mission approach presents conceptual similarities and links with the fourth-stage IC perspective. Consequently, it is possible to expand the third mission framework to include, and merge with, IC elements. In addition to this, it is possible to combine the considerations on the challenges faced by universities with the importance of universities in the IC field to adopt a broader approach. The Italian case, with the activity of ANVUR, especially through the 2011-2014 VQR model, could represent the starting point to do this: The efficiency, the effectiveness, and the value of research and third mission activities are evaluated with indicators that are related to IC components. On the basis of these considerations, Secundo et al. [24] built a model for assessing and evaluating third mission activities, by considering IC. The third mission framework could, thus, imply a greater interaction of the university's internal elements and the external environment, with stronger and more effective links between the three components of intellectual capital, i.e., human capital, structural capital, and relational capital.

These considerations on the repositioning of the goals of research and science towards a greater socio-economic outcome, as was mentioned, have been at the heart of an intense academic debate, which led to the creation of several models and approaches (e.g., Mode 1 and 2; triple, quadruple, and quintuple helix models; entrepreneurial university; third mission). Several studies have tried to define appropriate indicators and methods to measure and evaluate the contribution of universities to social and economic value, with the perspective of improving quality assurance, allowing institutions, governments, and the private sector to understand how they perform, to develop best practices, and to provide efficient and effective value for society. Despite these efforts, however, research is still far from reaching a general agreement on a set of indicators to evaluate the new role of universities, also because it is not always easy to notice, since it does not always result in measurable income or tangible monetary returns. Future research starting from the model by Secundo et al. [2] will certainly provide systematic insights on the measurement and evaluation of third mission processes, by considering the possibility of a fifth stage of research [24], generated by bidirectional relationships between human and 
relational capital, with the aim of exploring the role of IC in everyday life in a wider social environment. An additional issue is raised by the interdisciplinary nature of the third mission, which makes the identification of the phenomenon more complicated due to the involvement of various fields in the implemented actions.

Concerning the Italian context, recent reforms have addressed the measurement gap of third mission activities as public outcome. In particular, the National Agency for the Evaluation of University and Research Systems, ANVUR, has moved from a perspective based on the output, only considering the number of third mission activities carried out by each university, to a perspective based on the process, where a set of indicators (patents, spin-off companies, third-party research, intermediaries, continuous education, clinical research and training, production and management of cultural heritage, public engagement) is subject to a qualitative evaluation from a commission of experts. This is certainly an important initiative that can at least reduce the diffused lack of systemic vision, as well as the difficulty to assess and measure the value and impact of such activities. However, the risk is that the profound meaning of third mission activities is downgraded to an empty bureaucratic task. To avoid this, the academic community should fully grasp the importance of the university in the socio-economic development of the territory where it is located, and also the importance of the territory in the socio-economic development of the university. The future of the university then depends on its ability to create an interdependent and interactive relationship with its surroundings.

According to Secundo et al. [122], a combination of IC management with a collective intelligence approach is needed to avoid IC discourse becoming theoretically and practically irrelevant; in this sense, all stakeholders would understand how an organization takes into account its ethical, social, and environmental impacts [24]. At the same time, the involuntary IC disclosures coming from different categories of stakeholders could be dangerous, by representing an opportunity, but also a threat for educational institutions, given its ability to influence public opinion and public policy $[24,85]$.

Given the limitations of international rankings and projects for the evaluation and comparability of university third mission activities, intellectual capital can act as an assessment tool for third mission performance, as well as an empowering and facilitating tool for stimulating third mission activities in higher education institutions. It is important to build a new, reliable, and replicable evaluation framework, which should ideally be created by networks of academics [24] and then be tested within universities in order to understand whether they are really able to provide useful insights in the evaluation process. Thus, implications are interesting for both academics, who should be directly included in the framework building process, and policy institutions, which are interested in assessing third mission activities and in providing systemic approaches. Limitations include the newness of studies providing evaluation frameworks, which need to be further applied and tested with the internal and external stakeholders; this aspect is also mentioned in the presentation of the model by Secundo et al. [24]. Moreover, it is important to analyze how national and international institutions, currently designing and providing the evaluation frameworks, will react to new research.

Future research should focus on the importance of engaging several categories of stakeholders in carrying out the activities of the university: As highlighted by Secundo et al. [123], collective intelligence is a key element in considerations on third mission, thus, further research should be devoted to the role of universities in supporting growth and innovation within society. A systematization of different crowdsourcing approaches adopted in universities could also be useful in order to enrich the elaborations on third mission and to further the engagement of various stakeholders.

Author Contributions: Conceptualization, R.F. and N.C.; formal analysis, R.F. and N.C.; investigation, R.F. and C.F.; methodology, N.C.; project administration, R.F.; supervision, R.F. and G.F.; validation, N.C. and G.F.; writing-original draft, all authors.

Funding: This research received no external funding.

Conflicts of Interest: The authors declare no conflict of interest. 


\section{References}

1. European Commission and OECD. A Guiding Framework for Entrepreneurial Universities; OECD: Paris, France, 2012.

2. Secundo, G.; Perez, S.E.; Martinaitis, Z.; Leitner, K.H. An Intellectual Capital framework to measure universities' third mission activities. Technol. Forecast. Soc. Chang. 2017, 123, 229-239. [CrossRef]

3. Powell, W.W.; Snellman, K. The Knowledge Economy. Annu. Rev. Sociol. 2004, 30, 199-220. [CrossRef]

4. Chesbrough, H. Open Innovation: The New Imperative for Creating and Profiting from Technology; Harvard Business School Press: Harvard, MA, USA, 2003.

5. Petty, R.; Guthrie, J. Intellectual capital literature review: Measurement, reporting and management. J. Intellect. Cap. 2000, 1, 155-176. [CrossRef]

6. Guthrie, J.; Ricceri, F.; Dumay, J. Reflections and projections: A decade of intellectual capital accounting research. Br. Account. Rev. 2012, 44, 68-92. [CrossRef]

7. Esposito, V.; De Nito, E.; Pezzillo Iacono, M.; Silvestri, L. Dealing with knowledge in the Italian public universities: The role of performance management systems. J. Intellect. Cap. 2013, 14, 431-450. [CrossRef]

8. Secundo, G.; Perez, S.E.; Martinaitis, Z.; Leitner, K.H. An intellectual capital maturity model (ICMM) to improve strategic management in European universities. J. Intellect. Cap. 2015, 16, 419-442. [CrossRef]

9. Vagnoni, E.; Oppi, C. Investigating factors of intellectual capital to enhance achievement of strategic goals in a university hospital setting. J. Intellect. Cap. 2015, 16, 331-363. [CrossRef]

10. Dumay, J.; Garanina, T. Intellectual capital research: A critical examination of the third stage. J. Intellect. Cap. 2013, 14, 10-25. [CrossRef]

11. Sanchez, P.; Elena, S. Intellectual capital in universities. J. Intellect. Cap. 2006, 7, 529-548. [CrossRef]

12. Etzkowitz, H.; Leydesdorff, L. The Triple Helix-university-industry-government relations: A laboratory for knowledge-based economic development. Easst Rev. 1995, 14, 14-19.

13. Etzkowitz, H.; Leydesdorff, L. The Dynamics of Innovation: From National Systems and "Mode 2" to a Triple Helix of University-Industry-Government Relations. Res. Policy 2000, 29, 109-123. [CrossRef]

14. Schumpeter, J. Capitalism, Socialism and Democracy; Harper and Row: New York, NY, USA, 1942.

15. Carayannis, E.; Campbell, D. Mode 3 Knowledge Production in Quadruple Helix Innovation Systems; Springer Briefs in Business: New York, NY, USA, 2012.

16. Carayannis, E.; Barth, T.; Campbell, D. The Quintuple Helix Innovation Model: Global Warming as a Challenge and Driver for Innovation. J. Innov. Entrep. 2012, 1, 2. [CrossRef]

17. Freeman, C. Technology Policy and Economic Performance: Lessons from Japan; Printers Publishers: London, UK, 1987.

18. Lundvall, B.-Å. Innovation as an Interactive Process-from User-Producer Interaction to National Systems of Innovation. In Technology and Economic Theory; Dosi, G., Ed.; Printers Publishers: London, UK, 1988.

19. Zawdie, G. Knowledge exchange and third mission of universities. Ind. High. Educ. 2010, 24, 151-155. [CrossRef]

20. Abatecola, G. Research in Organizational Evolution. What Comes Next? Eur. Manag. J. 2014, 32, 434-443. [CrossRef]

21. Cafferata, R. Darwinist connections between the systemness of social organizations and their evolution. J. Manag. Gov. 2014, 20, 19-44. [CrossRef]

22. Abatecola, G.; Belussi, F.; Breslin, D.; Filatotchev, I. Darwinism, Organizational Evolution and Survival: Key Challenges for Future Research. J. Manag. Gov. 2015, 20, 1-17. [CrossRef]

23. Ranga, M.; Etzkowitz, H. Triple Helix Systems: An Analytical Framework for Innovation Policy and Practice in the Knowledge Society. Ind. High. Educ. 2013, 27, 237-262. [CrossRef]

24. Secundo, G.; Dumay, J.; Schiuma, G.; Passiante, G. Managing intellectual capital through a collective intelligence approach. An integrated framework for universities. J. Intellect. Cap. 2016, 17, 298-319. [CrossRef]

25. Stewart, T.A. Intellectual Capital: The New Wealth of Organizations; Doubleday-Currency: London, UK, 1997.

26. Kerr, C. Godkin Lectures at Harvard University; Harvard University: Cambridge, MA, USA, 1963.

27. Leydesdorff, L.; Dolfsma, W.; Van der Panne, G. Measuring the knowledge base of an economy in terms of triple-helix relations among technology, organization, and territory. Res. Policy 2006, 35, 181-199. [CrossRef] 
28. Leydesdorff, L. Knowledge-Based Economy and the Triple Helix Model. Annu. Rev. Inf. Sci. Technol. 2010, 44, 367-417. [CrossRef]

29. Organization for Economic Co-operation and Development. Transition to Learning Economies and Societies; OECD: Paris, France, 1996.

30. Foray, D.; Lundvall, B.A. Employment and Growth in the Knowledge-based Economy; OECD Documents: Paris, France, 1996.

31. Stanback, T.M. Understanding the Service Economy: Employment, Productivity, Location; Johns Hopkins University Press: Baltimore, MD, USA, 1979.

32. Noyelle, T. Skills, Wages and Productivity in the Service Sector; Westview Press: Boulder, CO, USA, 1990.

33. Brynjolfsson, E.; Hitt, L.M. Beyond computation: Information technology, organizational transformation and business performance. J. Econ. Perspect. 2000, 14, 23-48. [CrossRef]

34. Gordon, R.J. Does the new economy measure up to the great inventions of the past? J. Econ. Perspect. 2000, 14, 49-74. [CrossRef]

35. Drucker, P.F. Post-Capitalist Society; Harper Bus: New York, NY, USA, 1993.

36. Nonaka, I.; Takeuchi, H. The Knowledge-Creating Company; Oxford University Press: Oxford, UK, 1995.

37. Nonaka, I. A dynamic theory of organizational knowledge creation. Organ. Sci. 1994, 5, 14-37. [CrossRef]

38. Abramowitz, M.; David, P.A. Technological change and the rise of intangible investments: The US economy's growth-path in the twentieth century. In Employment and Growth in the Knowledge-Based Economy; Foray, D., Lundvall, B.A., Eds.; OECD Documents: Paris, France, 1996.

39. Gibson, D.; Rogers, E. R E D Collaboration on Trial: The Microelectronics and Computer Technology Consortium; Harvard Business School Press: Harvard, MA, USA, 1994.

40. Feller, I.; Madden, P.; Kaltreider, L.; Moore, D.; Sims, L. The new agricultural and technology transfer policy agenda. Res. Policy 1987, 16, 315-325. [CrossRef]

41. Levin, M. Technology transfer as a learning and developmental process: An analysis of Norwegian programmes on technology transfer. Technovation 1993, 13, 497-518. [CrossRef]

42. Power, J.B.; McDougall, P. Policy orientation effects on performance with licensing to start-ups and small companies. Res. Policy 2005, 34, 1028-1042. [CrossRef]

43. Gibbons, M.; Limoges, C.; Nowotny, H.; Schwartzmann, S.; Scott, P.; Trow, M. The New Production of Knowledge; Sage: London, UK, 1994.

44. Carayannis, E.; Campbell, D. Triple Helix, Quadruple Helix and Quintuple Helix and how do knowledge, innovation and environment relate to each other? Int. J. Soc. Ecol. Sustain. Dev. 2010, 1, 44-69. [CrossRef]

45. Lee, S.; Bozeman, B. The impact of research collaboration on scientific productivity. Soc. Stud. Sci. 2005, 35, 673-702. [CrossRef]

46. Hessels, L.; Van Lente, H. Re-thinking new knowledge production: A literature review and a research agenda. Res. Policy 2008, 37, 740-760. [CrossRef]

47. Etzkowitz, H. The Triple Helix: University-Industry-Government Innovation in Action; Routledge: London, UK, 2008.

48. Sábato, J. El Pensamiento Latinoamericano en la Problematica Ciencia-Tecnologia-Desarrollo-Dependencia; Paidos: Buenos Aires, Argentina, 1975.

49. European Commission. The World in 2025. Rising Asia and Socio-Ecological Transition; European Commission: Brussels, Belgium, 2009.

50. Etzkowitz, H. Research groups as 'quasi-firms': The invention of the entrepreneurial university. Res. Policy 2003, 32, 109-121. [CrossRef]

51. Etzkowitz, H. The norms of entrepreneurial science: Cognitive effects of the new university-industry linkages. Res. Policy 1998, 27, 823-833. [CrossRef]

52. Molas-Gallart, J.; Salter, A.; Patel, P.; Scott, A.; Duran, X. Measuring Third Stream Activities: Final Report to the Russell Group of University, SPRU; University of Sussex: Sussex, UK, 2002.

53. Gunasekara, C. Refraiming the Role of Universities in the Development of Regional Innovation System. J. Technol. Transf. 2006, 31, 101-113. [CrossRef]

54. Pilbeam, C. Generating additional revenue streams in UK universities: An analysis of variation between disciplines and institutions. J. High. Educ. Policy Manag. 2006, 28, 297-311. [CrossRef]

55. Business/Higher Education Round Table. Universities' Third Mission: Communities Engagement, B-HERT Position Paper; B-HERT: Melbourne, Australia, 2006. 
56. Higher Education Funding Council for England. Strategic Plan 2006-11; HEFCE: London, UK, 2008.

57. Webber, R.; Jones, K. Re-positioning as a response to government higher education policy development-an Australian case study. J. High. Educ. Policy Manag. 2011, 33, 17-26. [CrossRef]

58. Bornmann, L. What Is Societal Impact of Research and How Can It Be Assessed? A Literature Survey. J. Am. Soc. Inf. Sci. Technol. 2013, 64, 217-233. [CrossRef]

59. Sánchez-Barrioluengo, M. Articulating the 'three-missions' in Spanish universities. Res. Policy 2014, 43, 1760-1773. [CrossRef]

60. Watson, D.; Hall, L. Addressing the Elephant in the Room: Are Universities Committed to the Third Stream Agenda. Int. J. Acad. Res. Manag. 2015, 4, 48-76.

61. Guerrero, M.; Cunningham, J.A.; Urbano, D. Economic impact of entrepreneurial universities' activities: An exploratory study of the United Kingdom. Res. Policy 2015, 44, 748-764. [CrossRef]

62. Boyer, E.L. Scholarship Reconsidered: Priorities of the Professoriate; The Carnegie Foundation for the Advancement of Teaching: Stanford, CA, USA, 1991.

63. Leydesdorff, L. The triple helix: An evolutionary model of innovations. Res. Policy 2000, 29, $243-255$. [CrossRef]

64. Benner, M.; Sandström, U. Institutionalizing the triple helix: Research funding and norms in the academic system. Res. Policy 2000, 29, 291-301. [CrossRef]

65. Clark, B.R. The Entrepreneurial University: Demand and Response. Tert. Educ. Manag. 1998, 4, 5-16. [CrossRef]

66. Carmona, S.; Ezzamel, M.; Gutiérrez, F. Towards an institutional analysis of accounting change in the royal tobacco factory of Seville. Account. Hist. J. 1998, 25, 115-147. [CrossRef]

67. Leitner, K.H.; Warden, C. Managing and reporting knowledge-based resources and processes in research organizations: Specifics, lessons learned and perspectives. Manag. Account. Res. 2004, 15, 33-51. [CrossRef]

68. Secundo, G.; Margherita, A.; Elia, G.; Passiante, G. Intangible assets in higher education and research: Mission, performance or both? J. Intellect. Cap. 2010, 11, 140-157. [CrossRef]

69. Cricelli, L.; Greco, M.; Grimaldi, M.; Llanes Duenas, L.P. Intellectual capital and university performance in emerging countries-Evidence from Colombian public universities. J. Intellect. Cap. 2018, 19, 71-95. [CrossRef]

70. Glewwe, P. Schools and skills in developing countries: Education policies and socioeconomic outcomes. J. Econ. Lit. 2002, 40, 436-482. [CrossRef]

71. Drucker, P.F. Managing in the Next Society; Routledge: London, UK, 2012.

72. Aubert, J.E.; Reiffers, J.L. Knowledge Economies in the Middle East and North Africa: Toward new Development Strategies; World Bank Publications: Washington, DC, USA, 2003.

73. Fazlagic, A. Measuring the Intellectual Capital of a University, Conference on Trends in the Management of Human Resources in Higher Education; OECD: Paris, France, 2016.

74. Leitner, K.H. Intellectual capital reporting for universities: Conceptual background and application for Austrian universities. Res. Eval. 2004, 13, 129-140. [CrossRef]

75. Bisogno, M.; Dumay, J.; Rossi, F.M.; Tartaglia Polcini, P. Identifying future directions for IC research in education: A literature review. J. Intellect. Cap. 2018, 19, 10-33. [CrossRef]

76. Turri, M. The new Italian agency for the evaluation of the university system (ANVUR): A need for governance or legitimacy? Qual. High. Educ. 2014, 20, 64-82. [CrossRef]

77. Ramiréz-Corcoles, Y.; Santos Penalver, J.F.; Tejada, A. Intellectual capital in Spanish public universities: stakeholders' information needs. J. Intellect. Cap. 2011, 12, 356-376. [CrossRef]

78. Di Bernardino, D.; Corsi, C. A quality evaluation approach to disclosing third mission activities and intellectual capital in Italian universities. J. Intellect. Cap. 2018, 19, 178-201. [CrossRef]

79. Melian-Gonzalez, A.; Batista-Canino, R.M.; Sanche-Medina, A. Identifying and assessing valuable resources and core capabilities in public organizations. Int. Rev. Adm. Sci. 2010, 76, 97-114. [CrossRef]

80. Canibano, L.; Sanchez, P. Intangibles in universities: Current challenges for measuring and reporting. J. Hum. Resour. Costing Account. 2009, 13, 93-104. [CrossRef]

81. Leitner, K.H.; Elena-Perez, S.; Fazlagic, J.; Kalemis, K.; Martinaitis, Z.; Secundo, G.; Sicilia, M.A.; Zaksa, K. A Strategic Approach for Intellectual Capital Management in European Universities: Guidelines for Implementation, Executive Agency for Higher Education and Research Funding of Romania (UEFISCDI); Blueprint Series: Bucharest, Romania, 2014. 
82. Sanchez, P.; Castrillo, R.; Elena, S. Intellectual capital dynamics in universities: A reporting model. J. Intellect. Cap. 2009, 10, 307-324. [CrossRef]

83. Elena-Pérez, S.; Saritas, O.; Pook, K.; Warden, C. Ready for the future? Universities' capabilities to strategically manage their intellectual capital. Foresight 2011, 13, 13-48. [CrossRef]

84. Corcoles, Y.R.; Ponce, A.T. Cost-benefit analysis of intellectual capital disclosure: University stakeholders' view. Rev. Contab. 2013, 16, 106-117.

85. Dumay, J. A critical reflection on the future of intellectual capital: From reporting to disclosure. J. Intellect. Cap. 2016, 17, 168-184. [CrossRef]

86. Corcoles, Y.R. Importance of intellectual capital disclosure in Spanish universities. OmniaScience 2013, 9 , 931-944.

87. Dambrin, C.; Lambert, C.; Sponem, S. Control and change-Analyzing the process of institutionalization. Manag. Account. Res. 2007, 18, 172-208. [CrossRef]

88. Campos, E.B. Gestion del Conocimiento en Universidades y Organismos Publicos de Investigacion; Direccion General de Investigation, Consejeria de Educacion: Madrid, Spain, 2003.

89. Feng, H.I.; Chen, C.S.; Wang, C.H.; Chiang, H.C. The role of intellectual capital and university technology transfer offices in university-based technology transfer. Serv. Ind. J. 2012, 32, 899-917. [CrossRef]

90. Martin-Sardesai, A.; Guthrie, J. Human capital loss in an academic performance measurement system. J. Intellect. Cap. 2018, 19, 53-70. [CrossRef]

91. Bontis, N. Intellectual capital: An exploratory study that develops measures and models. Manag. Decis. 1998, 36, 63-76. [CrossRef]

92. Bratianu, C. The intellectual capital of universities. In The Annals of the University of Oradea; Cohut, L.P., Zmole, E., Eds.; Oreda: Bucharest, Rumania, 2009.

93. Alcaniz, L.; Gomez, F.; Roslender, R. Theoretical perspectives on intellectual capital: A backward look and a proposal for going forward. Account. Forum 2011, 35, 104-117. [CrossRef]

94. Maldonado, J.R. Consideraciones para la medicion del capital intelectual en el sector publico, el caso de las universidades. Universidades 2013, 63, 56-67.

95. Silvestri, A.; Veltri, S. The intellectual capital report within universities: Comparing experiences. Econ. Sci. Ser. 2011, 20, 618-624.

96. Castellanos, A.R.; Rodriguez, A. University R\&D\&T capital: What types of knowledge drive it? J. Intellect. Cap. 2004, 5, 478-499.

97. Bezhani, I. Intellectual capital reporting at UK universities. J. Intellect. Cap. 2010, 11, 179-207. [CrossRef]

98. Piber, M.; Habersam, M.; Skoog, M. Ten years of using knowledge balance sheets in Austrian public universities - retrospective and perspective. J. Intellect. Cap. 2018, 19, 34-52.

99. Kim, D.Y.; Kumar, V. A framework for prioritization of intellectual capital indicators in R\&D. J. Intellect. Cap. 2009, 10, 277-293.

100. Habersbam, M.; Piber, M.; Skoog, M. Knowledge balance sheets in Austrian universities: The implementation, use, and re-shaping of measurement and management practices. Crit. Perspect. Account. 2013, 24, 319-337. [CrossRef]

101. Laredo, P. Toward a Third Mission for Universities; UNESCO research seminar for the Regional Scientific Committee for Europe and North America: Paris, France, 2007.

102. E3M Needs and Constraints Analysis of the Three Dimensions of Third Mission Activities; European Commission: Brussels, Belgium, 2012.

103. Rauhvargers, A. Global University Rankings and Their Impact-Report II; European University Association: Geneva, Switzerland, 2013.

104. Hazelkorn, E.; Loukkola, T.; Zhang, T. Rankings in Institutional Strategies and Processes: Impact or Illusion? European University Association: Geneva, Switzerland, 2014.

105. Altbach, P.G. The globalization of college and university rankings. Chang. Mag. High. Learn. 2012, 44, $26-31$. [CrossRef]

106. Van Vught, F.; Ziegele, F. Designing and Testing the Feasibility of a Multidimensional Global University Ranking; Consortium for Higher Education and Research Performance Assessment: Brussels, Belgium, 2011.

107. European Commission. Communication from the Commission to the European Parliament, the Council, the European Economic and Social Committe and the Committe of the Regions; European Commission: Brussels, Belgium, 2011. 
108. Observatory of European University. Methodological Guide, Final Report of the Observatory of the European University; PRIME Project: Wroclaw, Poland, 2006.

109. Dalkey, N.C. The Delphi method: An experimental study of group opinion. Futures 1969, 1, 408-426. [CrossRef]

110. Eto, H. The suitability of technology forecasting/foresight methods for decision systems and strategy. A Japanese view. Technol. Forecast. Soc. Chang. 2003, 70, 231-249. [CrossRef]

111. Linstone, H.A.; Turoff, M. The Delphi Method: Techniques and Applications; Addison-Wesley: Boston, MA, USA, 1977.

112. Woudenberg, F. An evaluation of Delphi. Technol. Forecast. Soc. Chang. 1991, 40, 131-150. [CrossRef]

113. Etzkowitz, H. Entrepreneurial Scientists and Entrepreneurial Universities in American Academic Science. Minerva 1983, 21, 198-233. [CrossRef]

114. Bercovitz, J.; Feldman, M. Entrepreneurial universities and technology transfer: A conceptual framework for understanding knowledge-based economic development. J. Technol. Transf. 2006, 31, 175-188. [CrossRef]

115. Guerrero, M.; Urbano, D. The development of an entrepreneurial university. J. Technol. Transf. 2010, 37, 43-74. [CrossRef]

116. National Agency for the Evaluation of the University and Research. Rapporto Sullo Stato del Sistema Universitario e Della Ricerca; ANVUR: Berlin, German, 2013.

117. National Agency for the Evaluation of the University and Research. Manuale Per la Valutazione Della Terza Missione Nelle Università Italiane; ANVUR: Berlin, Germany, 2015.

118. Kaufmann, L.; Schneider, Y. Intangibles: A synthesis of current research. J. Intellect. Cap. 2004, 5, 366-388. [CrossRef]

119. Sanchez, M.P.; Elena, S. La gestion estratégica de la Universidad contemporanea: Reflexiones sobre la potencialidad de los modelos de capital intellectual. Rev. De Invesigacion En Gest. De La Innov. Y Tecnol. 2007, 42, 1-10.

120. Sanchez, M.P. Papel de los intangibles y el capital intellectual en la creacion y dufusion del conocimiento en las organizaciones. Situac. Actual Y Retos De FutureArbor 2008, 184, 575-594.

121. Bueno, E.; Salmador, M.P.; Longo, M.S. Advances in the identification and measurement of intellectual capital and future developments in the intellectual capital research agenda: Experience of the intellectual model and proposal of a synthetic index. Knowl. Manag. Res. Pract. 2014, 12, 339-349. [CrossRef]

122. Dumay, J.; Garanina, T. Involuntary disclosure of intellectual capital: Is it relevant? J. Intellect. Cap. 2017, 18, 29-44. [CrossRef]

123. Secundo, G.; Massaro, M.; Dumay, J.; Bagnoli, C. Intellectual capital management in the fourth stage of IC research: A critical case study in university settings. J. Intellect. Cap. 2018, 9, 157-177. [CrossRef] 